\title{
Factors associated with scorpion stings in schoolchildren: cross-sectional study from two rural communities of Guerrero, Mexico
}

\author{
Rufino Silva-Domínguez ${ }^{1}$, Sergio Paredes-Solís ${ }^{2 *}$, Antonio J. Cortés-Guzmán ${ }^{1}$, Miguel Flores-Moreno ${ }^{2}$, \\ José G. Baldazo-Monsivaiz ${ }^{3}$, Neil Anderson ${ }^{2,4}$ and Anne Cockcroft ${ }^{4}$
}

${ }^{1}$ Secretaría de Salud de Guerrero, Chilpancingo, Guerrero, Mexico; ${ }^{2}$ Centro de Investigación de Enfermedades Tropicales, Universidad Autónoma de Guerrero, Acapulco, Guerrero, Mexico; ${ }^{3}$ Unidad Académica No. 13, Universidad Autónoma de Guerrero, Zihuatanejo, Guerrero, Mexico; ${ }^{4}$ Department of Family Medicine, McGill University, Montreal, Quebec, Canada

\begin{abstract}
Background: Scorpion stings represent a public health problem in Latin America and North America. The aim of this study was to identify species of medical importance, as well as to estimate the frequency of scorpion sting and the associatedrisk and protective factors in schoolchildren. Methods: Cross-sectional study in two rural communities in the Mexican state of Guerrero, in two phases: an entomological study that estimated the scorpion density and overcrowding index; a survey to document housing characteristics, poultry ownership, and history of scorpion sting in schoolchildren. Adjusted odds ratio (ORa) was used as a measure of association with scorpion sting in a multivariate analysis. Results: The species of medical importance were Centruroides limpidus and Centruroides balsasensis. Twelve percent $(171 / 1,437)$ of school children reported scorpion sting in the last six months, of whom seven out of ten required medical care. Four factors were associated with the report of scorpion sting: having ducks in the dwelling (ORa: 1.98; Cl 95\%: 1.2-4.29), lack of cleanliness in the dwelling (ORa: 1.84; Cl 95\%: 1.02-4.16), farming as an occupation (ORa: 1.53; Cl 95\%: 1.13-2.46) and dwelling with uncovered infrastructure of the roof, those made of woodliron sheet or cardboard (ORa: 1.42; Cl 95\%: 1.04-2.18). Conclusions: The most relevant species was Centruroides limpidus. Two factors might be particularly relevant to prevention: improvement of household roofing material and attention to housekeeping.
\end{abstract}

Key words: Scorpion sting. Associated factors. Schoolchildren.

Factores asociados con la picadura de alacrán en escolares: estudio transversal en dos comunidades rurales de Guerrero, México

\section{Resumen}

Introducción: La intoxicación por picadura de alacrán es un problema de salud pública en las regiones de América Lătina y América del Norte. El objetivo de este estudio fue identificar especies de alacrán de importancia médica, estimar la êcurrencia de accidentes por picadura de alacrán y factores asociados en la población de edad escolar. Métodos: Estüdio transversal en dos comunidades rurales de Guerrero, México, en dos fases: el estudio entomológico para estimar índices

Correspondence:

*Sergio Paredes Solís

E-mail: srgprds@gmail.com

2444-3409/๑ 2018. Hospital Infantil de México Federico Gómez, published by Permanyer México SA de CV, all rights reserved.
Date of reception: 23-08-2018

Date of acceptance: $14-11-2018$

DOI: 10.24875/BMHIME.M19000057
Available online: 14-01-2020 Bol Med Hosp Infant Mex. 2019;76:73-80 www.bmhim.com 
escorpionológicos y la encuesta a escolares que incluyó las características de sus viviendas, la tenencia de aves, los antecedentes de picadura de alacrán y variables relevantes. Se estimó la razón de momios ajustada (RMa) como medida de asociación al accidente por picadura de alacrán en los escolares mediante análisis multivariado. Resultados: Las espěcies de importancia médica fueron Centruroides limpidus y Centruroides balsasensis. El reporte de accidente por picadurä de alacrán en los últimos 6 meses en escolares fue del 12\% (171/1,437). Siete de cada diez escolares requirió de aterción médica. Fueron identificados cuatro factores asociados con el reporte de accidente por picadura de alacrán: tener pảtos en la vivienda (razón de momios ajustada [RMa]: 1.98; intervalo de confianza [IC] 95\%: 1.2-4.29), falta de aseo en la viejienda (RMa: 1.84; IC 95\%: 1.02-4.16), ayudar en la labor del campo (RMa: 1.53; IC 95\%: 1.13-2.46) y viviendas con material del techo no permanente (RMa: 1.42; IC 95\%: 1.04-2.18). Conclusiones: Centruroides limpidus fue la especie de importäncia médica más relevante. Fueron identificados dos factores asociados que son potencialmente modificables: mejorar el mâtêrial del techo de la vivienda y asear la vivienda.

Palabras clave: Picadura de alacrán. Factores asociados. Escolares.

\section{Introduction}

Scorpion envenomation is a public health problem in Latin America and North America., ${ }^{1,2}$ In Mexico, around 300,000 cases and 40 deaths are registered annually. ${ }^{3,4}$ Mortality in localities with less than 2,500 inhabitants is almost twelve times higher than that observed in those with more than 20,000 inhabitants. ${ }^{5}$ Recent records from the Secretaría de Salud (Ministry of Health) indicate an increase in its occurrence with rates of 8,618 per 100,000 inhabitants in 2012 and 8,769 per 100,000 population in 2013. The state of Guerrero ranked first in scorpion envenomation from 2012 to 2014, second in 2015 and third in 2016. ${ }^{4}$

Scorpions are found in almost all ecological environments. They are distributed mainly in tropical and subtropical regions, although they have adapted to hot desert environments. ${ }^{6}$ Until 2017, there were 2,342 species of scorpions in the world, ${ }^{7}$ of which only 50 species are dangerous for humans. ${ }^{8}$ In Mexico, 289 species are known, 19 of them are of medical importance, ${ }^{9}$ and inhabit mainly the Pacific coastal region. ${ }^{10}$

Toxic species that exist in Mexico belong to the genus Centruroides of the family Buthidae and are responsible for producing severe or fatal disease patterns. ${ }^{3,11}$ In Guerrero, for a long time, the only species of known medical importance was Centruroides limpidus. ${ }^{12}$ Currently, there are records of other species: Centruroides balsasensis, Centruroides tecomanus, Centruroides meisei, Centruroides villegasi, ${ }^{13}$ Centruroides bonito, ${ }^{14}$ and Centruroides poncei. ${ }^{15}$ The poison of these seven species is highly toxic.

The highest number of accidents by scorpion stings occur in rural populations at home and night. 8,16,17 Males have a higher frequency of accidents, ${ }^{18}$ and children under 15 years of age are the most affected, ${ }^{17}$ with the most severe clinical symptoms in children from 5 to
9 years of age. ${ }^{19,20}$ Precarious housing conditions ${ }^{21}$. and walking barefoot at night favor these accidents. 0 . The use of gloves by adult farmers during work has been observed as a protective factor, ${ }^{18}$ and no difference $h a s$ been observed in accidents by scorpion stings according to the socioeconomic status. ${ }^{22}$ The objective of this study was to identify the scorpion species of medical importance in two communities with a high incidence of scorpion envenomation and to estimate the occurrence of these accidents in schoolchildren and its-associated factors.

\section{Methods}

A cross-sectional study was conducted in two rural locations in the state of Guerrero, Mexico: Zumpango del Río and Atliaca. Zumpango del Río is the head of the Eduardo Neri municipality, which is located $1,050 \mathrm{~m}$ above sea level with the following coordinates $17^{\circ} 39^{\prime} 11.70^{\prime \prime} \mathrm{N}$ and $99^{\circ} 31^{\prime} 99^{\prime \prime}$ W. Approximately 24,500 inhabitants are living in the town ( $51 \%$ female), Sparish speakers. Zumpango has a temperate-tropical climate, and it rains from May to October. Its average temperature is $22^{\circ} \mathrm{C}$. The main activities of the population are commerce and agriculture. For its part, the community of Atliaca belongs to the municipality of Tixtla and is located $1,290 \mathrm{~m}$ above sea level with coordinates $17^{\circ} 39^{\prime} 10.57^{\prime \prime} \mathrm{N}$ and $99^{\circ} 22^{\prime} 23.64^{\prime \prime} \mathrm{W}$. It is occupied by approximately 7,200 inhabitants ( $51 \%$ female), of which $99 \%$ is indigenous. From this population, $78 \%$ speak Spanish and Nahuatl; $15 \%$ are only Spanish speakers, and $7 \%$, only Nahuatl speakers. The climate is hotcand dry, with a temperature that ranges between 25 and $37^{\circ} \mathrm{C}$. Agriculture is the main occupation.

The study comprised two phases: the first, from 2013 to June 2014, to identify scorpion species; the Second, from April to June 2016, to obtain information from 
Table 1. Formulas used for the estimation of scorpionism in the localities of Zumpango del Río and Atliaca, Guerrero, Mexico, 2013-2014

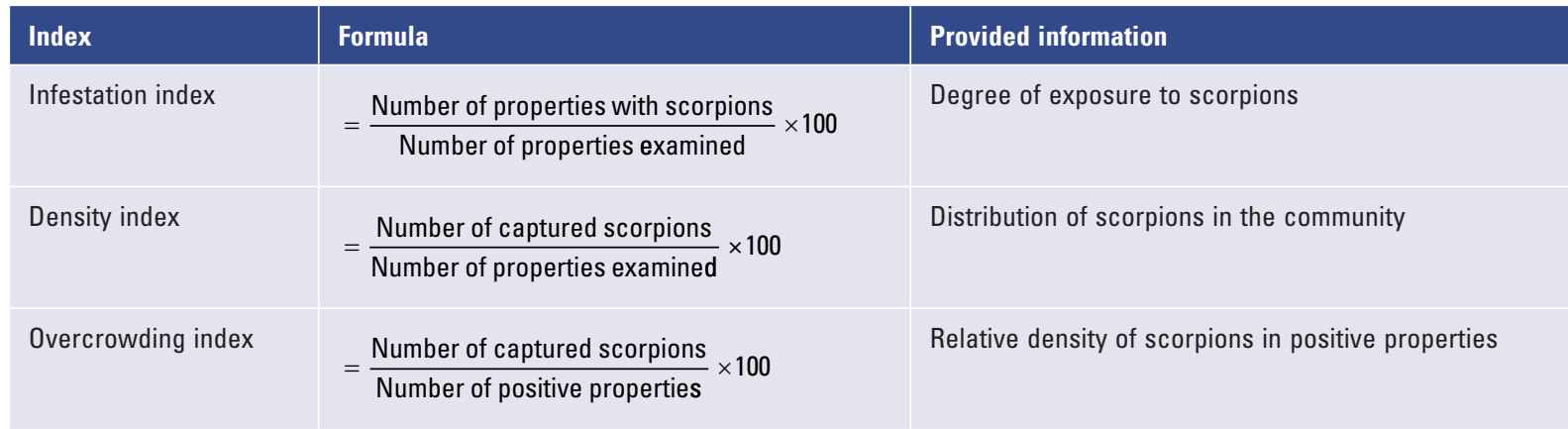

Source: Norma Oficial Mexicana NOM-033-SSA2-2011. Para la vigilancia, prevención y control de la intoxicación por picadura de alacrán (For the surveillance, prevention and control of scorpion sting poisoning). Published in the Diario Oficial de la Federación, Mexico, 22 November 2011.

schoolchildren related to the occurrence of accidents by scorpion stings and its associated factors.

\section{Entomological study}

The capturing of scorpions was carried out in ten peripheral neighborhoods of Zumpango del Río and six of Atliaca. Direct daytime capture methods were used. Active detection of scorpions was done mainly looking at ceilings, walls, fence posts, under cardboard sheets and rocks, and in piled tiles. The data was recorded in the ALER-1 format used by the Secretaría de Salud. ${ }^{23}$ For the species identification, the guidelines published by Baldazo et al..$^{13}$ and Ponce et al..$^{9}$ were used. With the collected specimens, the indices of infestation, density, and overcrowding were obtained, ${ }^{24}$ according to the formulas described in table 1.

\section{Survey of the schoolchildren}

The sample size was calculated with a $95 \%$ confidence interval $(95 \% \mathrm{Cl})$, power of $80 \%$, expected event rate of $10 \%$, and minimum odds-ratio (OR) to detect of 2.0. The result of the minimum number of observations was 948 . For logistical practicality, schoolchildren from all elementary schools in the localities were included, which guaranteed the covering of the minimum estimated sample size.

A measurement instrument was designed to estimate the number of accidents by scorpion stings and its associated factors. This instrument consisted of a questionnaire with 33 questions, which were validated by a round of experts. ${ }^{25}$ The working group was formed by a medical entomologist, an expert with a master's of science degree (both with experience in scorpionism) and two epidemiologists, one from the Secretaríâ de Salud of Guerrero and another from the Universidad Autónoma de Guerrero.

The questionnaire was applied to schoolchildren from fourth to sixth grade of primary education of all the schools belonging to the localities, three in Atliaca and eight in Zumpango del Río, in an ordinary day of atfendance to classes. A facilitator read the questions, and the students selected and marked their answers linformation was collected about the age, gender, and grade of schoolchildren, also conditions and materials of their home, bird ownership, knowledge about scorpions, perception of the danger by the students and consequences of contact with scorpions, and family and personal history of scorpion stings. Regarding scorpion stings experienced, the participants were asked about the date of the last time it occurred, affected part of the body, color of the scorpion, area where the scorpion was, area where the student was, symptoms, place where the student was treated, type of treatment, eost and if hospitalization was required. Also, the students were asked about their perception of the preventive actions against the scorpion stings and the history of deaths in their families due to scorpion envenomation. For the analysis, the occurrence of reported accidents by scorpion stings in the last six months was considered an outcome variable.

The analysis was carried out with the CIETmap-statistical software. ${ }^{26}$ The OR and $95 \% \mathrm{Cl}$ of the variables included in the bivariate and multivariate analysis were estimated with the Mantel-Haenszel procedure.7 The 95\% Cls were adjusted for cluster sampling usingothe method proposed by Lamothe. ${ }^{28}$ The multivariate analysis was used to estimate associations with independent effect starting with the saturated model, which 
included the variables that reached statistical significance, and eliminating one by one the factors that did not maintain statistical confidence $(p<0.05)$ until the final model remained.

The collected information was confidential, anonymous, and the school authorities and parents or guardians authorized the application of the survey. The objective of the study was explained to the students, and they decided to answer or not the questionnaire. The protocol was registered and authorized in the Local Research Committee of the Facultad de Ciencias Químico Biológicas (Faculty of Biological Chemistry Sciences) and the Centro de Investigación de Enfermedades Tropicales (Center for Research on Tropical Diseases) of the Universidad Autónoma de Guerrero.

\section{Results}

Centruroides limpidus was the main species of medical importance identified in both municipalities: $98 \%$ of the specimens identified in Zumpango del Río (344/350) and Atliaca (364/374) corresponded to this species. The most relevant results of the entomological study are shown in table 2.

A total of 1,437 students from fourth to sixth grade of primary education were surveyed: $24 \%(348 / 1,437)$ from Atliaca schools, and $76 \%(1,089 / 1,437)$ from Zumpango del Río. Forty-nine percent of the students $(699 / 1,437)$ were male; the average age was 10.6 years (range 9 to 13). Table 3 shows some characteristics of the homes of schoolchildren.

A high percentage of schoolchildren (97\%; $1,394 / 1,437)$ recognize scorpions and $94 \%(1,351 / 1,437)$ consider them dangerous. Of the respondents, $85 \%$ $(1,221 / 1,429)$ know that they should see a physician after a scorpion sting; $25 \%(359 / 1,437)$ know that they should shake their clothes; $16 \%(227 / 1,437)$ that they should check before wearing their shoes; and $40 \%$ $(577 / 1,435)$ of participants use protections on their beds.

At least one accident by scorpion sting was reported in the lifetime of $36 \%(522 / 1,437)$ schoolchildren. In the last 6 months, $12 \%(171 / 1,435)$ reported accidents by scorpion stings: $13 \%(91 / 697)$ were males and $11 \%$ (80/737) were females $(p=0.19)$. Also, $5 \%(68 / 1,436)$ of schoolchildren reported that a relative died because of a scorpion sting. Of the respondents who underwent at least one scorpion sting accident, 45\% (233/522) mentioned that the scorpion was yellow, while $54 \%$ (284/522) suffered the sting in the hand/arm, and 36\% (190/522) in the leg/foot. At the moment of the sting, 65\% (340/522)
Table 2. Main results of the entomological study in the localities of Zumpango del Río and Atliaca, Guerrero, Mexico, 2013-2014

\begin{tabular}{|c|c|c|c|}
\hline Entomological indicator & $\begin{array}{l}\text { Zumpango del } \\
\text { Río }\end{array}$ & \multicolumn{2}{|c|}{ Atliaca } \\
\hline Examined properties & 70 & 60 & 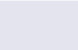 \\
\hline $\begin{array}{l}\text { Positive properties } \\
\text { (scorpion presence) }\end{array}$ & 40 & 40 & $\begin{array}{l}\text { (0) } \\
\frac{1}{u}\end{array}$ \\
\hline Specimens captured & 445 scorpions & 465 scor & pions \\
\hline Infestation index & 57 & 67 & $\frac{}{2}$ \\
\hline Density index & 636 & 623 & $\stackrel{0}{\simeq}$ \\
\hline Overcrowding index & 1,113 & 935 & 4 \\
\hline Specimens identified & 350 scorpions $^{a}$ & 374 scorp & pions ${ }^{b}$ \\
\hline $\begin{array}{l}\text { Main identified scorpion } \\
\text { species }\end{array}$ & & & $\frac{\tilde{n}}{\varepsilon}$ \\
\hline Centruroides limpidus & 344 & 364 & 을 \\
\hline Mesomexovis variegatus & 1 & 2 & $\stackrel{ \pm}{ \pm}$ \\
\hline Centruroides balsasensis & 3 & - & $\sum$ \\
\hline Mesomexovis atenango & 1 & - & 은 \\
\hline Hoffmannihadrurus gertschi & 1 & - & $\frac{2}{0}$ \\
\hline Vaejovis curvidigitus & - & 8 & $\begin{array}{l} \pm \\
\pm\end{array}$ \\
\hline
\end{tabular}
were damaged.

Table 3. Housing characteristics of schoolchildren of Atliaca and Zumpango del Río, Guerrero, Mexico, 2016

\section{Factor} $\mathbf{N}=\mathbf{1 , 4 3 7} \%$

Material of walls

Cement

Brick

Adobe

Wood

Iron sheet

Floor

Cement

Tile

Earthen

Roof

Cement

Tile

Iron sheet, wood, cardboard

430

74

177

33

To use firewood for cooking

829

463

143

To store firewood inside the house.

813

92

523

608

To use protections on their beds

622

577

To store building material inside the house 
Table 4. Bivariate analysis of factors associated with scorpion stings reported in the last six months by schoolchildren from Atliaca and Zumpango del Río, Guerrero, Mexico, 2016

\begin{tabular}{|c|c|c|c|c|}
\hline Factor & Scorpion stings & No scorpion stings & ORu & $95 \% \mathrm{Cl}$ ac \\
\hline $\begin{array}{l}\text { House with earthen floor } \\
\text { Yes } \\
\text { No }\end{array}$ & $\begin{array}{c}28 \\
115\end{array}$ & $\begin{array}{c}142 \\
1,148\end{array}$ & 1.97 & $1.36-2.8$ \\
\hline $\begin{array}{l}\text { House roof of non-permanent materials } \\
\text { Yes } \\
\text { No }\end{array}$ & $\begin{array}{c}78 \\
444\end{array}$ & $\begin{array}{c}93 \\
811\end{array}$ & 1.53 & $1.11-2$ \\
\hline $\begin{array}{l}\text { Use firewood for cooking } \\
\text { Yes } \\
\text { No }\end{array}$ & $\begin{array}{c}95 \\
512\end{array}$ & $\begin{array}{c}76 \\
751\end{array}$ & 1.83 & $1.41-2.39$ \\
\hline $\begin{array}{l}\text { Having chickens in the dwelling } \\
\text { Yes } \\
\text { No }\end{array}$ & $\begin{array}{c}70 \\
350\end{array}$ & $\begin{array}{l}101 \\
913\end{array}$ & 1.81 & $1.21-2.70$ \\
\hline $\begin{array}{l}\text { Having ducks in the dwelling } \\
\text { Yes } \\
\text { No }\end{array}$ & $\begin{array}{l}21 \\
68\end{array}$ & $\begin{array}{c}150 \\
1,195\end{array}$ & 2.46 & $1.52-3$ \\
\hline $\begin{array}{l}\text { Children help in the countryside work } \\
\text { Yes } \\
\text { No }\end{array}$ & $\begin{array}{c}51 \\
237\end{array}$ & $\begin{array}{c}119 \\
1,025\end{array}$ & 1.85 & $1.3-2.64$ \\
\hline $\begin{array}{l}\text { Lack of cleanliness in the dwelling } \\
\text { Yes } \\
\text { No }\end{array}$ & $\begin{array}{l}22 \\
81\end{array}$ & $\begin{array}{c}149 \\
1,182\end{array}$ & 2.17 & $1.54-3.0$ \\
\hline
\end{tabular}

$95 \% \mathrm{Cl}$ ac, $95 \%$ confidence interval adjusted by cluster; $0 \mathrm{Ru}$, unadjusted odds ratio.

of schoolchildren were inside their home, 15\% (79/522) in the yard, $2 \%(9 / 522)$ at school, $6 \%(32 / 522)$ in the countryside, and $12 \%(62 / 522)$ in an unspecified place. Schoolchildren (68\%) were treated in a hospital or health center (355/522), while $30 \%$ (156/522) in their home with home remedies, and $1.4 \%(6 / 522)$ by traditional healers. Of the cases, $61 \%(317 / 522)$ were treated with fabotherapy (antivenom therapy), and 249 schoolchildren (48\%) were hospitalized.

Furthermore, $4 \%(23 / 522)$ of schoolchildren with an accident by scorpion sting reported no symptoms. In schoolchildren with symptoms, 33\% (165/499) reported mild pain, 36\% (181/499) suffered severe pain at the site of the sting, and $31 \%$ (153/499) presented one or more of the following symptoms: vomiting, loss of color sight, foreign body sensation in the pharynx, and fainting.

In terms of costs, $78 \%(409 / 522)$ of schoolchildren with an accident by scorpion sting did not know the cost of care, and $4 \%(21 / 522)$ reported that their care was free of charge. For 74 cases (14\%), the cost ranged from 10 to 1,000 Mexican pesos.

The bivariate analysis identified seven variables associated with the scorpion sting reports in the last six months. Two factors were related to the housing conditions, the soil material, and the roof material; two other factors were related to having birds, chickef or ducks, inside the dwelling, and three, to family habits: cooking with firewood, the help of children in the countryside work and lack of cleanliness in the dwelling. Table 4 shows the associated factors identified in the bivariate analysis with the estimate of the OR andithe $95 \% \mathrm{Cl}$ adjusted by cluster $(95 \% \mathrm{Cl}$ ac).

In the final multivariate analysis model, four factors maintained an independent effect on the scorpion sting reports during the last six months. The highest association force was observed with the factor of having ducks in the dwelling (adjusted odds ratio (ORa): 198 , $95 \% \mathrm{Cl}$ ac: 1.20-4.29), then with the housekeeping factors, the help of children in the countryside work-and the presence of non-permanent materials on the house roof. Table 5 presents the details of the ORa andithe $95 \% \mathrm{Cl}$ ac in the multivariate analysis.

\section{Discussion}

Centruroides limpidus was the main species of a scorpion with medical importance found in this stady. 
Table 5. Final multivariate analysis model of factors associated with scorpion stings reported in the last six months by schoolchildren from Atliaca and Zumpango del Río, Guerrero, Mexico, 2016

\begin{tabular}{|c|c|c|c|c|c|}
\hline Factor & $\mathrm{ORu}$ & ORa & $95 \%$ Cl ac & $x^{2 \text { het }}$ & p \\
\hline Having ducks in the dwelling & 2.15 & 1.98 & $1.20-4.29$ & 10.37 & 0.99 \\
\hline Lack of cleanliness in the dwelling & 1.86 & 1.84 & $1.02-4.16$ & 8.03 & 0.9 \\
\hline The child help in the countryside work & 1.71 & 1.53 & $1.13-2.46$ & 7.86 & 0.54 \\
\hline House roof of non-permanent materials & 1.46 & 1.42 & $1.04-2.18$ & 6.09 & 0.83 \\
\hline
\end{tabular}

Accidents due to scorpion stings suffered in the last six months were $12 \%$ in schoolchildren, and the associated factors were the presence of ducks in the dwelling, lack of cleanliness in the dwelling, helping in the countryside work, and living in a house with a roof made with non-permanent materials.

In the state of Guerrero, the most widespread scorpion species is Centruroides limpidus, ${ }^{11}$ although there are other species in smaller proportions. Almost all the scorpions collected in the entomological study corresponded to Centruroide limpidus, and only three specimens of Centruroide balsasensis were identified in Zumpango del Río. Because of this finding, the probability that scorpion sting accidents reported by schoolchildren involved Centruroides limpidus, a scorpion species with high toxicity, ${ }^{12}$ is considered high.

Scorpionism in both locations was similar. The infestation index indicates the close coexistence of scorpions with humans, while the density index suggests a broad distribution of the scorpions in the community. The overcrowding index reveals a high clustering of scorpions in domiciles. The results of the indices suggest that the localities have appropriate conditions as scorpion habitat.

Currently, there are no classifications of the risk level of accidents by scorpion stings based on scorpionism. In particular, these localities were selected based on the records of scorpion envenomation from the Secretaría de Salud of Guerrero. The findings of the indices confirm that communities with a high degree of exposure to this type of accident were chosen. The capturing of scorpions was carried out during the day since there were no safety conditions to do it at night. In this sense, it should be noted that these indices are underestimated since scorpions are nocturnal animals.

The interviewed schoolchildren reported the color of the scorpion (yellow), which allowed determining that the scorpions corresponded to the species Centruroides limpidus and Centruroides balsasensis since they are the only ones with these characteristics; the other scorpion species are brown. The accidents occurred in and around the house $(80 \%)$, which is explained by the high overcrowding index. One-third of scorpion stings were presented in the foot. It has been reported that walking barefoot favors these accidents. ${ }^{17}$ However, in the present study, the use of footwear was no questioned. Seven out of ten children who reported a scorpion sting were treated at a hospital or health center, which indicates the high envenomation severity, another characteristie of Centruroides limpidus stings. ${ }^{6}$

Two of the four factors associated with scorpion stings obtained from the final model of the multivatiate analysis are related to housing conditions: having ducks and the lack of cleanliness in the dwelling: The other two familial socioeconomic conditions included having non-permanent materials on the house roofand the help of children in the countryside work. Consequently, it is considered that families living in a temporary dwelling (made of iron, wood, or cardboard sheets) and those families in which schoolchildren join the countryside work, represent the most vulnerable populations from an economic point of view. This finding is different from that reported by Almeida et al., in Brazill. 22 It is known that precarious housing conditions favor accidents by scorpion stings. ${ }^{17}$

As this is a cross-sectional study, it has the limitation of not evaluating the temporal relationship between exposure and effect. Reasonably, it would be expected that the identified associated factors (such as the tack of cleanliness in the dwelling, household roofing material, and to help in the countryside work) precedent the sting. However, it is not the same in case of the association between scorpion stings and having ducks in the dwelling. There is the undocumented report that ducks feed on scorpions and that they are less yumerable to scorpion stings due to their long thick beak, 
which cannot be penetrated by the scorpion. If this version is correct, the association would explain that the presence of ducks is a response of the people to diminish the density of scorpions in the house. Another possibility is that the presence of these birds together with the materials needed to house them (mainly woods, cardboard, and straw) create a favorable habitat for the scorpions. Other investigations should explore these hypotheses.

From an epidemiological point of view, housing conditions are essential for scorpion stings to occur. The respondents reported that the walls of their houses were made of brick, wood, adobe and iron sheets, and the roofs of non-permanent materials, such as iron sheets and wood, which are ideal shelter sites for scorpions.

Although the study was not intended to measure details of the costs of medical care, most schoolchildren were unaware of the amount paid for scorpion sting treatments and care. The study of the frequency of health services, the cost of the treatments, the hospitalization time, and disability days in severe cases demand specific investigations on the estimate of the costs incurred by the families and health services.

Improving housing conditions and preventing children from working in the countryside represents a cost for families. However, presenting the expenses of the care of a person with scorpion envenomation provides, at least, a framework to compare the cost and benefit of these decisions. Also, these data would serve to protect the rest of the family members. The same results help government authorities to reorient public spending in municipalities where scorpion envenomation is a significant health problem.

\section{Ethical disclosures}

Protection of human and animal subjects. The authors declare that no experiments were performed on humans or animals for this study.

Confidentiality of data. The authors declare that they have followed the protocols of their work center on the publication of patient data.

Right to privacy and informed consent. The authors declare that no patient data appear in this article.

\section{Funding}

None.

\section{Acknowledgments}

To parents and schoolchildren who collaborated dwith us and shared their experiences. To civil and educational authorities of Zumpango del Río and Atliaca we acknowledge their commitment to school health We want to thank Lucero Andraca Ponce, Abigail Silva Bedolla, and Félix Calzada García, bachelors in Biology of the Facultad de Ciencias Químico Biológiéas, Universidad Autónoma de Guerrero, for their colläboration in the fieldwork of this study.

\section{References}

1. Borges A, Miranda JR, Pascale JM. Scorpionism in Central America, with special reference to the case of Panama. J Venom Anim Toxins incPTrop Dis. 2012;18:130-43

2. Isbister GK, Bawaskar HS. Scorpion envenomation. N Engl J己Med. 2014;371:457-63.

3. Villa-Manzano Al, Vázquez-Solís MG, Zamora-López XX, Arias-Corôna F, Palomera-Ávila FM, Pulido-Galaviz C, et al. Alacranismo severo causante de parálisis flácida aguda. Reporte de caso. Rev Med Inst Mex Seguro Soc. 2016;54:265-8.

4. Secretaría de Salud. Boletín Epidemiológico. Sistema Nacional de Vigilancia Epidemiológica. Sistema Único de Información. 2017. Available at: https://www. gob.mx/salud/acciones-y-programas/direccion-general-de-epidemiologia-boletin-epidemiologico.

5. Celis A, Gaxiola-Robles R, Sevilla-Godínez E, Orozco Valerīo MJ, Armas J. Tendencia de la mortalidad por picaduras de alacrán en México, 1979-2003. Rev Panam Salud Publica. 2007;21:373-80.

6. Possani LD. El alacrán y su piquete. Dirección General de Divulgación de la Ciencia, UNAM; 2005.

7. Rein JO. The scorpion files. Trondheim, Noruega University of Seience and Technology; 2017. Available at: http://ntnu.no./ub/scorpion-files/.

8. Silva MSV, Silva Cláudio GL, Silva Neto B, Grangeiro Júnior+CRP, Lopes VHG, Teixeira Júnior AG, et al. Clinical and epidemiological aspects of scorpionism in the world: a systematic review. Wilderness Environ Med. 2016;27:504-18.

9. Ponce-Saavedra J, Francke BOF, Quijano-Ravell AF, Cortés Santittán R. Alacranes (Arachnida: escorpiones) de importancia para la salud pública en México. Folia Entomol Mex. 2016;2:45-70.

10. Santibañez-López CE, Francke OF, Ureta C, Possani LD. Scorpionsfrom Mexico: from species diversity to venom complexity. Toxins (Bäsel). 2015;8:pii: E2.

11. Quijano-Ravell AF, Ponce-Saavedra J, Francke OF, Villaseñor-Ramos MA. Nuevos registros y distribución actualizada de Centruroides tecomanus Hoffmann, 1932 (Scorpiones: Buthidae). Ciencia Nicolaita. 2010;52: 179-89.

12. Villegas A, Andersson N, Martinez E. Alacranismo en Guerrero: Un estudio epidemiológico en 20 comunidades. Salud Publica Mex. 1988 ; 30:234-9.

13. Baldazo-Monsivaiz JG, Ponce-Saavedra J, Flores-Moreno M. Alacranes (Arachnida: scorpionida) de importancia médica del estado de Guerrero, México. Dugesiana. 2012;19: 143-50.

14. Quijano-Ravell AF, Teruel R, Ponce-Saavedra J. A new Centruroides Marx, 1890 (Scorpiones: Buthidae), from Southern Guerrero State,Mexico. Rev Iber Aracnol. 2016;8:25-34.

15. Teruel R, Kovarik F, Baldazo-Monsivaiz JG, Hoferek D. A new spècies of Centruroides of the "nigrovariatus" group (Scorpiones: Buthidae) from southern Mexico. Revista Iber Aracnol. 2015;26:3-14.

16. Ebrahimi V, Handami E, Moemenbellah-Fard MD, Ezzatzadegan-Jahromi E. Predictive determinants of scorpion sting in a tropical zone of south Iran: use of mixed seasonal autoregressive moving average model. J Venom Anim Toxins Incl Trop Dis. 2017;23:39.

17. Celis A, Gaxiola-Robles R, Sevilla-Godínez E, Orozco Valerio MJ Armas J. Tendencia de la mortalidad por picaduras de alacrán en México, 1979-2003. Rev Panam Salud Publica. 2007;21: 373-80.

18. Villegas-Arrizón A, Garzón-Mayo R, Flores-Moreno M, Anderssoñ $\bar{N}$. E uso de guantes como factor protector contra picaduras de alacrán durante la pizca de maíz en el estado de Guerrero, México. Salud Publica Mex. 2009;51:126-33.

19. Guerra CM, Carvalho LF, Colosimo EA, Freire HB. Analysis of variables related to fatal outcomes of scorpion envenomation in children andadolescents in the state of Minas Gerais, Brazil, from 2001 to 2005. J Pediatr (Rio J). 2008;84: 509-15. 
20. Bahloul M, Chabchoub I, Chaari A, Chtara K, Kallel H, Dammak H, et al. Scorpion envenomation among children: clinical manifestations and outcome (analysis of 685 cases). Am J Trop Med Hyg. 2010;83:1084-92.

21. Consejo Nacional de Evaluación de la Política de Desarrollo Social. Available at: http://www.coneval.org.mx/coordinacion/entidades/Guerrero/Paginas/carencias-sociales20102015.aspx.

22. Almeida TS, Fook SM, França FO, Monteiro TM, Silva EL, Gomes LC et al. Spatial distribution of scorpions according to the socio-economic conditions in Campina Grande, State of Paraíba, Brazil. Rev Soc Bras Med Trop. 2016;49:477-85.

23. Thirión Icaza J, Losoya Solís A. Entomología con énfasis en control de vectores. Manual de procedimientos para el estudio entomológico de alacranes y su registro. Mexico: Secretaría de Salud;1997.
24. Norma Oficial Mexicana NOM-033-SSA2-2011. Para la vigilancia- prevención y control de la intoxicación por picadura de alacrán. Diario Óficial de la Federación;2011.

25. Escobar-Pérez J, Cuervo-Martínez A. Validez de contenido y juicio de expertos: una aproximación a su utilización. Avances en Medición. 2008; 6:27-36.

26. Andersson N, Mitchell S. CIETmap: Free GIS and epidemiology software from the CIETgroup, helping to build the community voice into-planning. Montreal: World Congress of Epidemiology; 2002.

27. Mantel N. Haenszel W. Statistical aspects of the analysis of data from retrospective studies of disease. J Natl Cancer Inst. 1959:22:719-48.

28. Lamothe G. Adjusting the Mantel Haenszel test statistic and odds ratio for cluster sampling. BMC Health Serv Res. 2011;11:S2-15 